\title{
Cultural Contradictions of Global Capitalism
}

\author{
Phillip Anthony O'Hara
}

In The Cultural Contradictions of Capitalism, Daniel Bell (1976) found that the decline of the bourgeois value system was brought about largely by the bourgeois economic system itself. In his opinion, the traditional values of American capitalism associated with the puritan temper and the protestant ethic were, from perhaps the 1960 s onward, in conflict with the rising postmodern temper of the avant-garde and the "different." He believed that the economic system promoted avant-garde cultural values into the mainstream of the realm of cultural industries and that this was in conflict with the spirit of work, trust, and stability. The capital ist economic system, therefore, necessarily propelled a cultural fabric that was against capitalism, and this was said to lead to many problems of system reproducibility. Advances in hedonism, "being all that one can," a consumption ethic, sexual liberty, and status emulation were in contradiction with the old values of frugality, industry, justice, modesty, and humility; and this would lead to many problems for capitalism. As a consequence, capitalism is said to have no coherent moral or philosophical doctrine to spur the system into motion as a positive motivational and inspirational force.

The ideas for this book were developed before the contradictions started to impact materially on the system, an early version of the idea emerging in 1969-70. Since Bell wrote this work others have proffered an account of the dominant cultural contradictions of capitalism (e.g., see Stanfield 1995), but Bell was one of the first to analyze such contradictions in the late twentieth century. However, his threefold dichotomy between social structure (economy), polity, and culture hardly helps comprehend the generalized cultural contradictions of the system, since for him culture is defined primarily as the

The author is the Director of the Global Political Economy Research Unit and Associate Professor, Department of Ecomom. ics, Curtin University, Perth, Australia. This paper was presented at the annual meeting of the Association for Evolutionary Economics, San Diego, Califomia, January 3-5, 2004. The author wishes to thank Pamela Jackson, Reynold Nesiba, Ron Stanfield, and Richard Brinkman for comments and/or encouragement on the issues dealt with in the paper. Emaril: philohara@runbox.com. 
industries associated with art, theatre, film, advertising, and so on. A far better view of culture is that developed by institutionalists, for instance by Anne Mayhew, as follows:

[C]ulure [is] the whole of a people's patterns of regular and recurring behaviour. . . The idea [is] that human behaviour, belief, thought and artefact [arel all cultural patterns... [ [E]mphasis |is| placed on the interrelatedness of component parts of culture, and upon cultural change as a consequence of that interrelatedness... . For all institutionalists who have followed the precepts of Veblen, Commons and Mitchell, culture has remained a central focus. . . For institutional economists, with the concept of culture as their foundation, . . studies of economic processes must, therefore, be holistic in approach. Change in conomic institutions is always part of more general socioreconomic change, always involves cumulative causation and is always path-dependent. (Mayhew 1994, 115-117; cmphases added)

The cultural contradictions of global capitalism, therefore, must be holistically engrained in the system. They are complex, following the general lines of cultural cvolution of the times, forever changing yet always emanating from the complex interactions that are the hallmark of global capitalism. They must be able to penetrate the dominant institutions, interact with other aspects of culture, and manifest to varying degrees through historical time. It is in this vein that we investigate the contemporary cultural contradictions of global capitalism.

\section{The Dominant Contradictions}

So what are the dominant cultural contradictions of global capitalism in the contemporary environment? First we need to comprehend the notion of contradiction. A contradiction is something endogenous to a complex system that is both central to its positive operational dynamics and a necessary negative outcome of its modus operandi. Central to the notion of contradiction is that there are positive and negative aspects that simulameously emerge from the dynamics of change and evolution. In general, the positives cannot exist without the negatives since they are part and parcel of the same procosses (O'Hara 2001). The nature of the outcomes within these processes change through time, depending upon how the institutions, habits, and instincts operate and interact. During some periods, the outcomes can be generally progressive, while at other times they can be regressive, depending upon the balance of outcomes. The balance of forces change, and this illustrates that the notion of contradiction secks to be a realistic, even pragmatic, and policy-relevant tool of conceptual analysis of the concrete workings of the system.

The dominant contemporary contradictions of global capitalism are obvious enough, and emanate from visions linking the works of Karl Marx, Thorstein Veblen, Joseph Schumpeter, John Maynard Keynes, and Karl Polanyi. It is necessary to investi- 
gate, firstly, the general contradictions of capitalism and then to see how they manifest and become modified through time. The general cultural contradiction of cafitalism relates to the (positive) stylized fact that it is a revolutionary system, one that seeks to create new innovations, penetrate new markets, create new industries, engender skill development, and cast aside fetters to its development wherever possible. Capitalism could not exist without the creative cultural process of continual innovation, competition, accumulation, and growth operating incessantly through time over many continents, nations, and regions. The cultural system and its agents seek opportunitics for greater profitability, economic rents, and monopoly privileges while at the same time being subject to new methods and ways of doing, and new agents and firms entering the process. Capital. ism thus establishes itself by necessity as a global system in the sense of forever trying to cast aside barriers to its motion. It potentially enables people's livelihood to be enhanced as it propels material advancement.

An inextricable part of these dynamic cultural elements is for the advancement of wants, desires, and needs of the population of consumers. As Doug Brown (2002) recognized, the population as a whole is enculturated in the values of consumption, "being all they can be," enhancing their capabilities, and climbing up the ladder of success and esteem. This is essential for the positive elements of capitalism to be enhanced and comtinually advanced to a new level. People's desires need to be seen as insatiable, subject to limitless capacity for creative expansion. This is manifest in the creation of new fads, fashions, and styles in the global marketplace and the development of skills relevant to these market values.

The very competitiveness of capitalism requires that people see this as heing the progression of individualism, as skills, capabilities, potentialities, and new elements are developed to a higher level and certain people are being actualized to a greater extent. People need to travel to far away places, increase the quantity and quality of material possessions, become more hip than the next person, be better looking than they are, and be seen in the public eye wherever possible. These cultural norms are seen as part of the creative individual, despite the extent to which they are a product of the "social individual" (Davis 2003, Hodgson 2004). Table 1 provides a general indication of the trend of some of these positive elements over the past couple of decades, when foreign direct investment, high-tech exports, the Internet, and cell phones grew rapidly from a low base.

Table 1. Four Engines of Global Cultural Growth (1980-2001)

\begin{tabular}{lccc}
\hline \hline & 1980 & 1990 & 2001 \\
\hline 1. Foreign direct investment inflows (US\$b) & $\$ 59 \mathrm{~b}^{*}$ & $\$ 203 \mathrm{~b}$ & $\$ 735 \mathrm{~b}$ \\
2. High-tech manuf. exports (percent total man.) & 9 percent $^{*}$ & 15 percent & 23 percent $^{* * *}$ \\
3. Internet users (million) & 0.00 & 0.07 & 501 \\
4. Cell phone owners (per 1000 pop.) & 0 & $6^{* *}$ & 157 \\
\hline
\end{tabular}

Source: Adapted from UNCTAD 2002 (4, 93); World Bank 2003.

*1982; ${ }^{* *} 1992 ;{ }^{* * *} 2000$. 
These secmingly "positive"-or at least forward-looking-forces are inseparable from the destructive, uneven, unstable, alienating, inequitable forces that are part of the very process of capitalism's dynanic. The dominant contradictions of capital lay in the very nature of capital itself. Being able to penetrate new markets, fashions, continents, and regions necessitates its constantly expanding geographically. But the spatial limits are considerable, including the coordinating process of global production and demand and the potential for an increase in the time of circulation and for the inability to realize supply with demand. The need to create new branches of production leads to the demise of old tirms, industrics and skills, and hence to periodic structural unemployment, bankruptcy, and transition lags from one sector to another. The need for sufficient profit requires investment, but a system of persistent uncertainty and changing levels of confidence and expected profitability lead to business cycle upswings and downswings of a potentially volatile nature. The workings of individual capitals may be in opposition to the needs of the system, since what may be good for an individual firm and person may not promote the public goods of confidence, stability, and trust.

This paradox of individual wersus system requirements is a critical one for capitalism. For instance, profitability may be hindered if the gencral power of business is both much greater and also much less than that of workers. If business is too strong then wages may be too low, leading to insufficient demand for the system. But if business is too weak relative to workers, then wages may be too high as unemployment is historically low, leading to high costs of production (as well as greater demand). Both instances may lead to low investment and profitability via an increase in uncertainty for business as the climate for expansion is inhibited. System requirements may require some degree of balance between capital and labor, and hence to the development of agreements that balance such power through historical time.

Capitalism also requires a continual dialectic of innovation-competition-innovation and so on ad infinitum. If innovations are not followed by a suitable measure of competition, then rent-secking behavior on the part of firms, unions, or the state may lead to scleretic practices that inhibit productivity and advancenent. But if innovation is followed by too much competition such that profitability and expectations are diminished, then the system may be similarly inhibited leading to decreased accumulation and growth. Hence, some dynamic level of balance between innovation (or cooperation) and competition is necessary for a relatively smooth flow of capital accumulation and growth through time. Such a balince is as likely as a "fluke" and hence capitalism is forever being subject to varying levels of stability and instability, leading to an unstable pattern of accumulation, innovation, and growth.

The greatest contemporary contradiction of global capitalism, however, is its inability to be revolutionary and path breaking in establishing economic performance and accumulation during the long wave downswing of the 1970s-2000s. The great successes of capitalism lead many to surmise that the negatives are well worth the effort if the positives are strong enough. However, apart from the emergence of long wave upswing in East 
Asia-a notable achievenent-the positives have been especially weak since the advent of grobalization and neoliberalism, not only in the advanced nations but also in Latin America, Sub-Saharan Africa, and many of the transitional economies of castern Europe. Global capitalism, therefore, over recent decades has been a failure in terms of its ability to re-establish reasonable levels of profitability, accumulation, productivity, and growth, the very things that it prides itself on. Some of the relevant data are shown in table 2 . $^{2}$

The data clearly show that most growth figures were relatively high during the 1960 s (and 1950s) and then consistently and successively declined through the 1970s, $1980 \mathrm{~s}, 1990 \mathrm{~s}$, and 2000s. Despite the growth engines of FDI, exports, and innovation, global economic performance has become far worse. Clearly, the global corporate system has not succeded in propelling greater profitability, investment, productivity, and growth during the 1970s-2000s. Hence there is no indication whatsoever that a new global regime of accumulation is being developed, and therefore capitalism's lack of effective positive dynamics is failing to propagate a new long wave upswing (sec O'Hara 2005 for an analysis of causation).

The contradictions are not simply manifesting themselves in the business-material world but also in the world of psychological well-being, social stability, and environmental quality. Unsuccessful attempts over the past twenty to thirty years to regenerate capitalism's revolutionary spirit of greater productivity, accumulation, profit, and growth have adversely affected the psychological and social state of its people and non-human species. While growth of real GDP per capita has declined over the past fow decades, these figures understate the degree of lackluster performance. For instance, assessments of the Index of Sustainable Economic Welfare (ISEW)-or the Genuine Progress Index (GPI)-have demonstrated an absolute decline (or at best a stabilization), showing that GDP itself has overestimated the degree of well-being or performance. This is shown in figure 1 for nations from four continents (figures shown in domestic currency units).

We are interested in estimates of ISEW/GPI for nations in as many continents as possible. However, since no assessments have becn made for nations in Asia and Africa, we must do with nations in Europe, North America, South America, and Oceania. Ear-

Table 2. Global Profitability, Investment, Productivity, and GDP Growth (1950s-2000s, Decade Annual Averages)

\begin{tabular}{|c|c|c|c|c|c|c|}
\hline & $1950 s$ & $1960 s$ & $1970 \mathrm{~s}$ & $1980 \mathrm{~s}$ & $1990 \mathrm{~s}$ & $2000-02$ \\
\hline US 500 TNC profit rate* & 7.71 & 7.15 & 6.30 & 5.30 & 4.02 & 3.30 \\
\hline Global 500 TNC profit rate* & 5.48 & 3.68 & 3.38 & 2.66 & 2.46 & 1.80 \\
\hline Real global investment growth rate ${ }^{* *}$ & n.a. & 7.78 & 3.97 & 3.24 & 2.24 & 2.1 \\
\hline Global industry value added growth ${ }^{* *}$ & n.a. & n.a. & 3.36 & 2.59 & 1.92 & n.a. \\
\hline Global services value added growth ${ }^{* *}$ & n.a. & n.a. & 3.35 & 2.60 & 2.46 & n.a. \\
\hline Real per capita global GDP growth ${ }^{* *}$ & n.a. & 3.19 & 2.11 & 1.27 & 1.05 & 1.00 \\
\hline
\end{tabular}

Source: Adapted from Fortune Magazine 1954-2003; World Bank 2003.

${ }^{*}$ Fortune; ${ }^{* *}$ World Bank; n.a. = not available 
Figure 1. ISEW or GPI 1950-2000: Four Continents/Nations

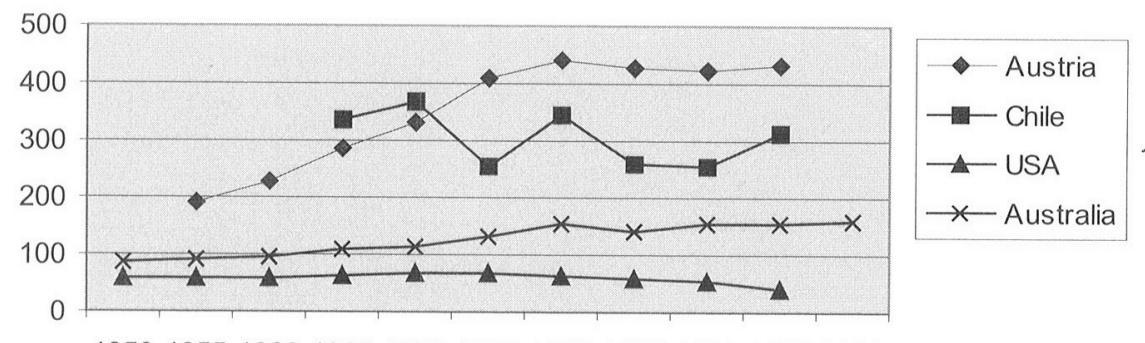

19501955196019651970197519801985199019952000

Source: Adapted from FOE 2002.

lier we saw that the rates of global growth and accumulation declined during the long wave downswing of the 1970s-2000s. Figure 1 additionally shows that conomic welfare also suffered substantially during the 1970s-2000s, after rising during the $1950 \mathrm{~s}$ and 1960 s.

'T he reasons for this have been the pressure of extra work, the costs of pollution and stress, and the instability associated with the breakdown of family and community relationships, factors linked to the "Threshold Hypothesis." Hence, the 1970-2000 period

Figure 2. GDP Excess over ISEW/GPI, 1950-2000: Four Continents/Nations

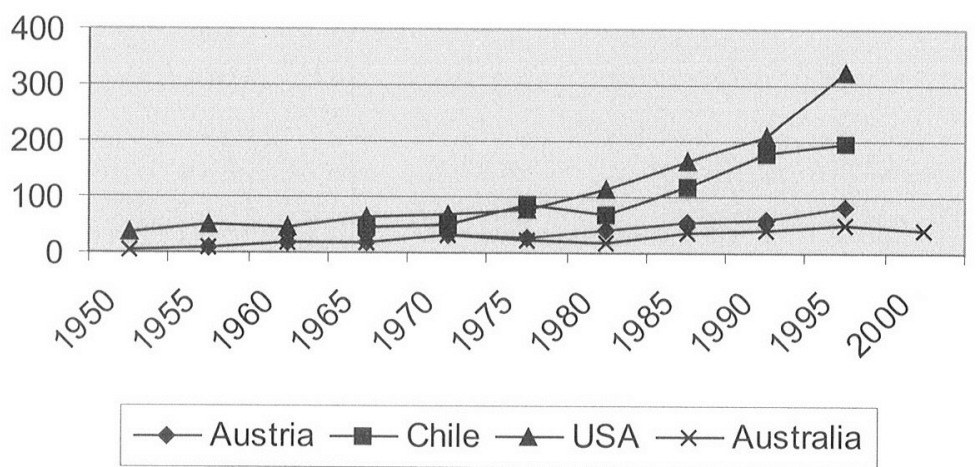

Source: Adapted from FOE 2002. 
has been characterized by greater social and environmental costs and pressures that have adversely affected the institutional and biospheric environments. The results of figure 2 (data shown in domestic currency units) illustrate that during the 1970s-1990s there has been between a moderate increase and an escalation in the extent that GDP overestimates the "psychic income" of nations (ISEW, GPI) due to greater levels of pollution, stress, overwork, greater inequality, and family/community breakclown. Not only has the long wave upswing adversely affected GDP growth in most nations and continents, it has also adversely affected welfare. The degree to which real GDP per capita does not reflect welfare is greater in the USA and Chile than in Austria and Australia, but the pattern of change is similar in all these nations.

\section{Conclusion}

Cultural contradictions are those that permeate critical aspects of the way of life of the people and the various economic agents and classes of global capitalism. Contradictions are positive and negative aspects of the social econony that are inextricably fuscd but which vary in nature and intensity over historical time. The main contradiction is that global capital's dynamic and revolutionary aspects-such as the penetration of FDI, high-tech exports, and innovations-create destructive elements in the system. These destructive elements are fused with the positive and represent things destroyed in the process of accumulation, growth, and innovation. These include skills, firms, and other institutions that people rely on for their way of life. Global capitalism is an unstable system because the positive and negative elements are systematically created and destroyed, respectively, through evolutionary and transformational processes.

The greatest contradiction of global capitalism is, however, that socioeconomic tensions have adversely affected accumulation and growth. As long wave downswing continues the very positive elements of capitalism decline through deteriorating economic performance. Worse still, sustainable welfare also diminishes as the net costs associated with trying to re-establish growth adversely affect the environment, levels of stress, and the social fabric. The cultural contradictions of contemporary global capitalism are considerable and must be seen as systemic elements and holistic processes operating in institutional space and time.

\section{Notes}

1. As Doug Brown said $(2004,209)$, "Yet in this new world of multiple subcultures, heterogeneity, diversity and the pastiche of life, fashion, style, conspicuous consumption, and emulation have found fertile ground. People are eager to embrace the latest fashion and the newest trends, ideas, subcultures, habits of the 'rich and famous', and all that's hip. They are hungry to be like those they see in the media, to cmulate the eclebrities, to hane out with the latest hipsters." 
2. The calculations of the rate of protit include aftertax corporate profit divided by corporate issets, times 100. Adjustments to the profit data have been undertiken for the period 19942002 wacount for the indusion of service corporations (row 1) and U.S. conporations (row 2) in table 2.

3. There are a number of other contradictions related to the workings of ghobal apitalism, induding (for instanes) those retating to the potential conflict between business and indestry, between production and repreduction, and between U.S. dominance and terrorism (see ()'llaril 2005).

\section{References}

Bell, 1). The Culturd Combadictions of Capitaliom. New York: Basic Books, 1976

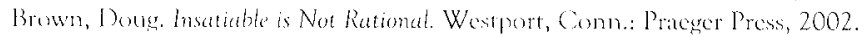

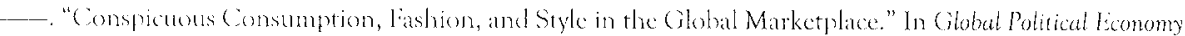

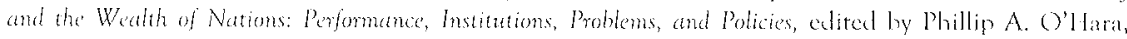
208-221. Iondon and New York: Routledge, 2004.

Davis, John. The Theory of the Indiriduat in Lionomics: Lentity and Value. London and New York: Routledge, 2003.

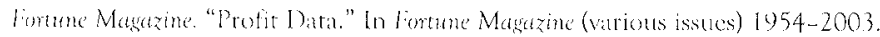

Friends of the Fanth (FOE). Medsume Prosess: Intemational hadiators. London: Friends of the tianth, 2002. http:/ www foecoluk/campaigns/sustamable development/progress/international.htoml.

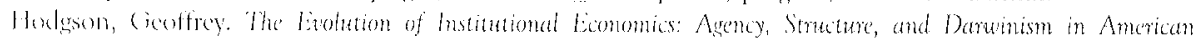
Insiantiondism. London and New York: Routleder, 2004.

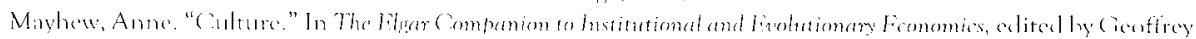

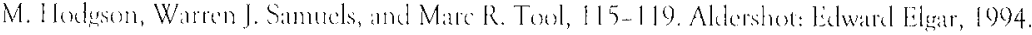

()'Hara, Phillip A. "Contadiction." In Enodopeder of Political Fonomy, edited by Phillip Anthony (')! lata, 140-143. London and New York: Routledere, 2001. Paperback Lelition.

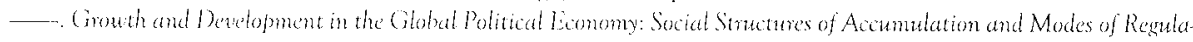
tiont. Lomblon and New York: Roullaloe, 2005

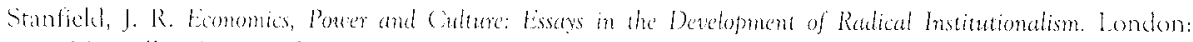
Macmilan; New York: St Martins, 1995.

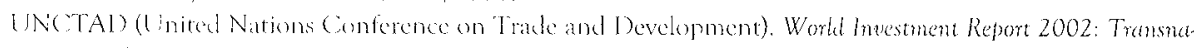
tionat Comporations and Export Competitueness. New York and Ceneva: United Nations, 2002.

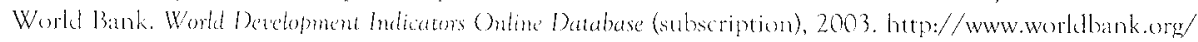
(aitis. 